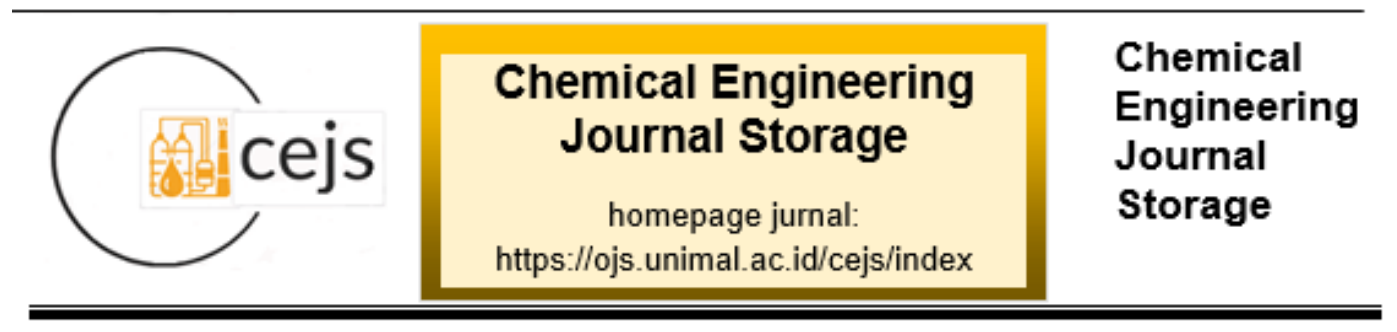

\title{
EKSTRAKSI BIJI OROK-OROK (CROTALARIA JUNCEA) SEBAGAI BAHAN BAKU PEMBUATAN BIODIESEL MENGGUNAKAN PELARUT N-HEKSAN
}

\author{
Mahyuni Marito, Azhari*, Meriatna, Suryati, Syamsul \\ Jurusan Teknik Kimia, Fakultas Teknik, Universitas Malikussaleh \\ Kampus Utama Cot Teungku Nie Reuleut, Muara Batu, Aceh Utara - 24355 \\ Korespondensi:e-mail: azhari@ unimal.ac.id
}

\begin{abstract}
Abstrak
Tanaman orok-orok (crotalaria juncea) adalah tanaman leguminosa yang termasuk kedalam keluarga perdu dan semak. Biji orok-orok dapat digunakan sebagai obat insomnia dan sebagai bahan baku pembuatan biodiesel karena mengandung 12,6\% minyak dengan 46,8\% asam linoleate. 4,6\% asam linolenat, $28,3 \%$ asam oleat dan 20,3\% asam jenuh. Untuk mendapatkan minyak dari biji orok-orok yang akan digunakan sebagai bahan baku biodiesel dapat dilakukan dengan metode ekstraksi padat-cair menggunakan pelarut N-Heksan. Pada penelitian ini bahan baku yang digunakan adalah biji orok-orok dan N-Heksan. Biji orok-orok dihaluskan menggunakan blender, kemudian dimasukkan dalam labu leher tiga untuk proses ekstraksi menggunakan pelarut $\mathrm{N}$-Heksan. Ekstraksi dilakukan dengan memvariasikan suhu ekstraksi dan volume pelarut dengan waktu ekstraksi 5 jam dan bahan baku sebanyak 100 gr. Setelah selesai ekstraksi larutan disaring menggunakan kertas saring. Selanjutnya dilakukan pemisahan antara minyak dan pelarut dengan proses destilasi. Pengujian yang dilakukan adalah uji densitas, yield, kadar FFA, viscositas, densitas dan uji komposisi dengan alat GC-MS. Densitas terendah dihasilkan pada suhu $50^{\circ} \mathrm{C}$, berat sampel $100 \mathrm{gr}$, waktu ekstraksi 5 jam dan volume pelarut sebanyak $400 \mathrm{ml}$ sebesar 1 $\mathrm{g} / \mathrm{ml}$. Yield tertinggi dihasilkan pada suhu $60^{\circ} \mathrm{C}$, berat sampel $100 \mathrm{gr}$, volume pelarut $700 \mathrm{ml}$ dan waktu ekstraksi 5 jam sebesar 35,52\%. Kadar FFA terendah dihasilkan pada suhu $50^{\circ} \mathrm{C}$, berat sampel $100 \mathrm{gr}$, volume pelarut $500 \mathrm{ml}$ dan waktu 5 jam sebesar 1,39\%. Viscositas hasil terbaik yang didapatkan adalah pada volume $700 \mathrm{ml}$ dengan waktu ekstraksi 5 jam menggunakan pelarut $N$ Heksan pada suhu $60^{\circ} \mathrm{c}$ sebesar $1 \mathrm{cp}$. Dari hasil uji GC-MS diketahui bahwa minyak biji orok-orok mengandung methyl ester of undecanoic acid, 2methylpentanoic acid, myristic acid methyl ester, methyl linolelaidate, 2cyclopentylacetohydrazide dan 2-methylpentanoic acid.
\end{abstract}

Kata kunci: Biji Orok-Orok, n-Heksan, Ekstraksi, viscositas, yield, kadar FFA, GC-MS 


\section{Pendahuluan}

Indonesia merupakan salah satu negara penghasil minyak bumi di dunia namun sampai saat ini masih mengimpor bahan bakar minyak (BBM) untuk mencukupi kebutuhan bahan bakar minyak di sektor transportasi dan energi. Kenaikan harga minyak mentah dunia akhir-akhir ini memberi dampak yang besar pada perekonomian nasional, terutama dengan adanya kenaikan harga BBM. Kenaikan harga BBM secara langsung berakibat pada naiknya biaya transportasi, biaya produksi industri dan pembangkitan tenaga listrik. Dalam jangka panjang impor BBM ini akan makin mendominasi penyediaan energi nasional apabila tidak ada kebijakan pemerintah untuk melaksanakan penganekaragaman energi dengan energi terbaharukan.

Ide penggunaan minyak nabati sebagai pengganti bahan bakar diesel didemonstrasikan pertama kalinya oleh Rudolph Diesel ( \pm tahun 1900). Penelitian di bidang ini terus berkembang dengan memanfaatkan beragam lemak nabati dan hewani untuk mendapatkan bahan bakar hayati (biofuel) dan dapat diperbaharui (renewable). Perkembangan ini mencapai puncaknya di pertengahan tahun 80-an dengan ditemukannya alkil ester asam lemak yang memiliki karakteristik hampir sama dengan minyak diesel fosil yang dikenal dengan biodiesel. Pembuatan biodiesel dari minyak nabati dilakukan dengan mengkonversi trigliserida (komponen utama minyak nabati) menjadi metil ester asam lemak, dengan memanfaatkan katalis pada proses metanolisis/esterifikasi. Beberapa katalis telah digunakan secara komersial dalam memproduksi biodiesel. Selain itu, juga diupayakan katalis katalis dari sisa produksi alam seperti, janjang sawit, abu sekam padi dan sebagainya. (Martini,2005)

Biodiesel adalah salah satu bahan bakar alternatif yang ramah lingkungan,tidak mempunyai efek terhadap kesehatan yang dapat dipakai sebagai bahan bakar kendaraan bermotor yang dapat menurunkan emisi bila dibandingkan dengan minyak diesel. Biodiesel terbuat dari minyak nabati yang berasal dari sumber daya alam yang dapat diperbaharui. Bahan baku yang berpotensi sebagai 
bahan baku pembuat biodiesel antara lain kelapa sawit, kedelai, jarak pagar, alpukat, biji orok-orok dan beberapa jenis tumbuhan lainnya. (Tiara, 2019) Salah satu tumbuhan yang mengandung minyak nabati adalah biji orok-orok (Crotalaria Juncea). orok-orok (crotalaria juncea) adalah tanaman leguminosa yang termasuk kedalam keluarga perdu dan semak. Biji orok-orok dapat digunakan sebagai obat insomnia dan sebagai bahan baku pembuatan biodiesel karena mengandung 12,6\% minyak dengan 46,8 \% asam linoleate. 4,6 \% asam linolenat, $28,3 \%$ asam oleat dan $20,3 \%$ asam jenuh. Untuk mendapatkan minyak dari biji orok-orok yang akan digunakan sebagai bahan baku biodiesel dapat dilakukan dengan metode ekstraksi padat-cair. (Plantamor, 2008).

\section{Bahan dan Metode}

Bahan dan peralatan yang diperlukan dalam penelitian ini antara lain adalah, Biji orok-orok, n-Heksan, seperangkat alat ekstraksi, beaker glass, labu leher tiga, hot plate, gelas ukur, spatula, thermometer, Erlenmeyer, stirrer, GCMS, corong gelas, corong pemisah, kertas saring, bola hisap, condenser, aluminium foil dan blender. Untuk mendapatkan hasil penelitian yang diinginkan dan analisnya, digunakan variable-variabel sebagaimana dibawah ini. Variabel Tetap biji orok-orok yang sudah di blender sebanyak 100 gr, waktu ekstraksi 5 jam, konsentrasi pelarut n-Heksan $80 \%$, kecepatan pengadukan $400 \mathrm{rpm}$. Variabel bebas yaitu volume bahan baku dengan pelarut 1:4, 1:5, 1:6, 1:7 dengan suhu ekstraksi $50^{\circ} \mathrm{c}, 55^{\circ} \mathrm{c}, 60^{\circ} \mathrm{c}$. Variabel Terikat yaitu uji FFA, densitas, viscositas, yield, GC-MS.

Penelitian ini terdiri dari tiga tahap: tahap pertama persiapan biji orok-orok di blender kemudian di keringkan sampai kadar air tidak ada, tahap kedua biji orok-orok dimasukkan dengan pelarut kedalam labu leher tiga dengan perbandingan 1:4, 1:5, 1:6, 1:7 dengan diatur suhu pemanasan $50^{\circ} \mathrm{c}, 55^{\circ} \mathrm{c}, 60^{\circ} \mathrm{c}$ kemudian dijalankan proses ekstraksi selama waktu yang sesuai dengan variable 5 jam. Hasil ekstraksi dimasukkan kedalam erlenmeyer dan dipisahkan ekstraksi dengan residunya. Lapisan polar dan non polar dipisahkan dengan corong 
pemisah, lapisan polar akan di destilasi sampai minyak yang dihasilkan tidak mengandung pelarut lagi. Tahap ketiga minyak biji orok-orok di uji kadarnya menggunakan alat GC-MS dan uji densitas, viscositas, yield, FFA.

\section{Hasil dan Diskusi}

\subsection{Perbandingan Volume Pelarut dan Suhu Ekstraksi Terhadap Yield (\%)}

Adapun grafik perbandingan volume pelarut dan suhu ekstraksi terhadap yield minyak biji orok-orok dapat dilihat pada Gambar 4.1 dibawah ini.

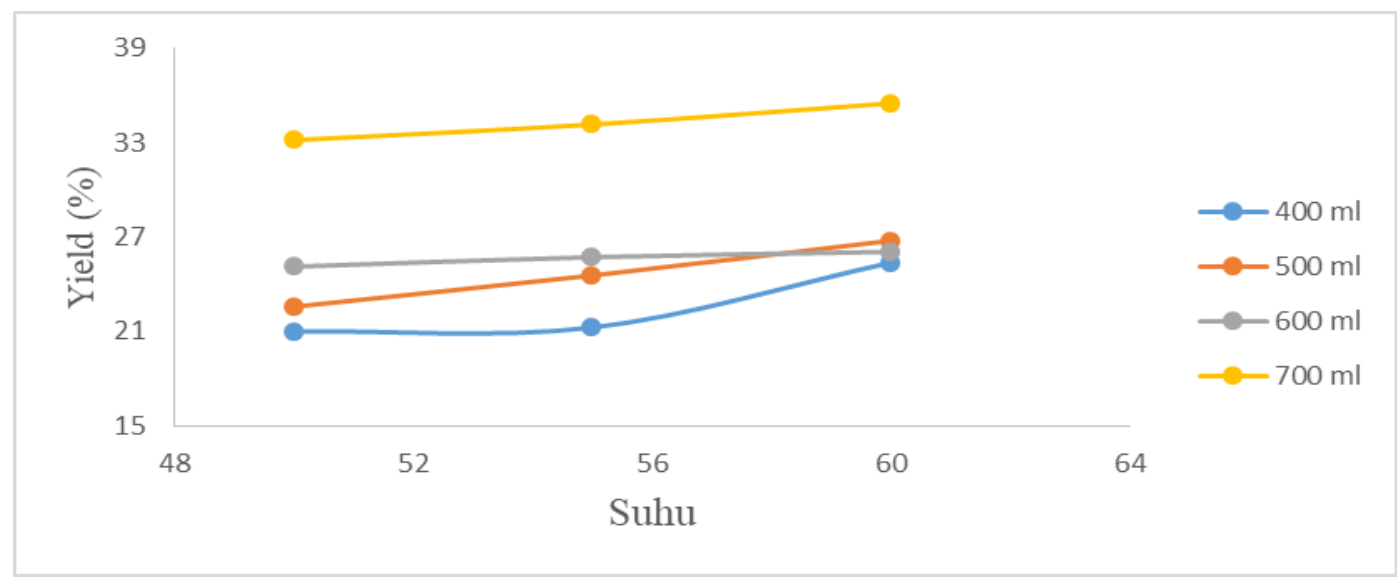

Gambar 4.1 Grafik Perbandingan Volume Pelarut dan Suhu Ekstraksi Terhadap Yield Minyak Biji Orok-Orok Menggunakan Pelarut n-Heksan.

Dari Gambar 4.1. Pengaruh suhu terhadap proses ekstraksi ditinjau dari kenaikan solubilitas pelarut yang akan memudahkan pelarut masuk dalam poripori padatan yang akan diekstrak (Jayanuddin, 2014). Gambar 4.1 menunjukkan bahwa kenaikan suhu dapat menyebabkan terjadinya kenaikan yield pada minyak. Hal ini disebabkan karena semakin tinggi suhu ekstraksi maka akan semakin banyak minyak yang terlarut. Proses ekstraksi adalah suatu aplikasi dari proses perpindahan massa, suhu merupakan salah satu faktor yang mempengaruhi kecepatan perpindahan massa. Peningkatan suhu dapat menyebabkan peningkatan solubilitas pelarut dan dapat memperbesar pori padatan, sehingga pelarut masuk melalui pori-pori padatan dan melarutkan component padatan yang terjerap kemudian zat terlarut berdifusi keluar permukaan partikel padatan dan bergerak ke lapisan film sekitar padatan, selanjutnya ke larutan (Ramadhan, 2010) Selain itu, dapat dilihat juga bahwa semakin besar volume pelarut yang digunakan, maka 
rendemen minyak kacang tanah yang didapat juga semakin besar. Kemudian jenis pelarut juga mempengaruhi rendemen minyak yang dihasilkan.

Kadar yield paling rendah terdapat pada waktu 5 jam, volume pelarut $100 \mathrm{ml}$ dan suhu $50^{\circ} \mathrm{C}$. Dan kadar yield paling tinggi terdapat pada waktu 5 jam, volume pelarut $700 \mathrm{ml}$ dan suhu $60^{\circ} \mathrm{C}$. Hal ini disebabkan oleh perbedaan waktu dan suhu, dan volume. Semakin banyak volume yang digunakan dan semakin tinggi suhu yang digunakan maka akan semakin besar yield yang didapat (Moeksin, 2018).

\subsection{Perbandingan Volume Pelarut dan Suhu Ekstraksi Terhadap Densitas}

Adapun grafik perbandingan volume pelarut dan waktu ekstraksi terhadap densitas minyak biji orok-orok dapat dilihat pada Gambar 4.2 dibawah ini.

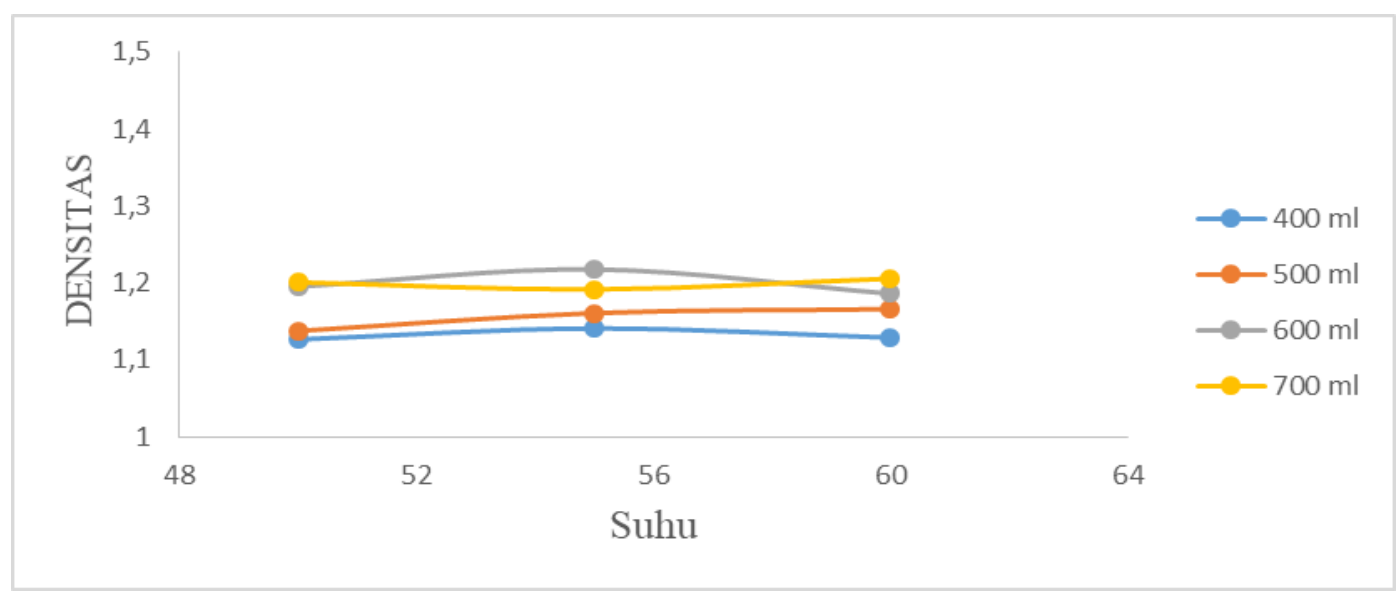

Gambar 4.2 Grafik Perbandingan Volume Pelarut dan Suhu Ekstraksi Terhadap Densitas Minyak Biji Orok-Orok Menggunakan Pelarut n-Heksan.

Densitas atau berat jenis minyak merupakan kumpulan berat molekul dari berbagai komponen penyusun suatu minyak dalam volume yang telah ditentukan. Harga densitas berkaitan dengan fraksi berat komponen yang terdapat dalam minyak. Berat molekul senyawa berbanding lurus dengan densitas minyak. Semakin berat molekul suatu senyawa maka akan semakin besar densitas minya (Hadrah, 2018). Dari gambar 4.2 dapat dilihat bahwa semakin besar volume pelarut yang digunakan, maka berat jenis minyak biji orok-orok yang dihasilkan akan semakin tinggi mendekati berat jenis minyak yang distandarkan. Hal ini disebabkan karena konsentrasi minyak biji orok-orok semakin meningkat dengan adanya penambahan volume pelarut. Dimana kemampuan pelarut menjadi lebih 
besar dalam mengekstrak biji orok-orok menjadi minyak biji orok-orok. Begitu juga dengan suhu yang digunakan, semakin tinggi suhunya densitas yang dihasilkan semakin besar. Gambar 4.2 Menunjukkan densitas paling rendah dihasilkan pada suhu $50^{\circ} \mathrm{C}$ dengan berat sampel $100 \mathrm{gr}$ dan volume pelarut $400 \mathrm{ml}$ densitas minyak sebesar $1 \mathrm{gr} / \mathrm{ml}$, sedangkan densitas minyak tertinggi adalah sebesar 1,2176 pada suhu $55{ }^{\circ} \mathrm{C}$ dan volume pelarut $600 \mathrm{ml}$ dengan berat sampel 100 gr. Densitas merupakan perbandingan berat dari suatu volume sampel dengan berat air pada volume yang sama. Perbedaan densitas disebabkan oleh perbedaan berat sampel pada saat penelitian. Semakin banyak sampel yang diberikan maka semakin besar densitas yang didapat. Tidak terdapat interaksi antara suhu ekstraksi dan densitas, karena densitas merupakan sifat fisik dari minyak.

\subsection{Perbandingan Volume Pelarut dan Suhu Ekstraksi Terhadap Viskositas}

Adapun grafik perbandingan volume pelarut dan Suhu ekstraksi terhadap viskositas minyak kacang tanah dapat dilihat pada Gambar 4.3 dibawah ini.

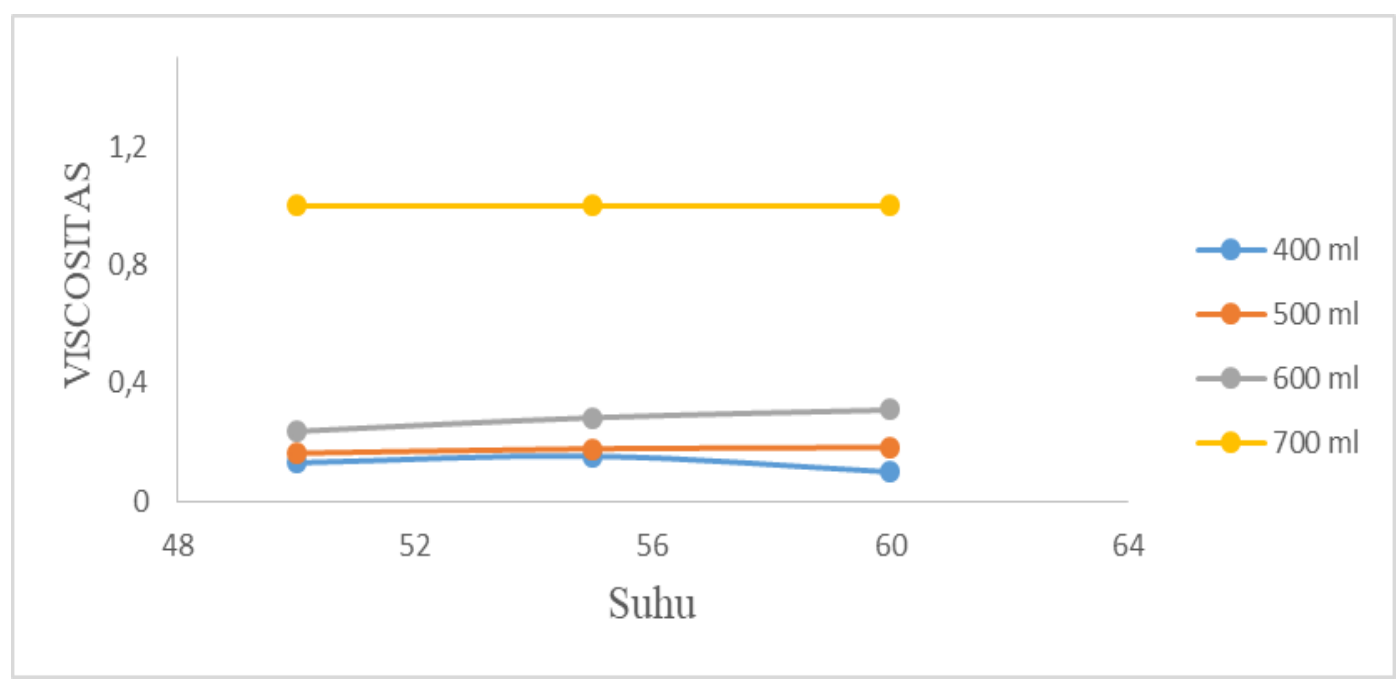

Gambar 4.3 Grafik Perbandingan Volume Pelarut dan Suhu Ekstraksi Terhadap Viscositas Minyak Biji Orok-Orok Menggunakan Pelarut n-Heksan..

Dari gambar 4.3 dapat dilihat bahwa kekentalan minyak meningkat seiring dengan peningkatan waktu ekstraksi. Hal ini berarti semakin cepat waktu yang diperlukan fluida untuk mengalir, maka semakin rendah viskositas fluida tersebut. Demikian sebaliknya, semakin lama waktu yang yang diperlukan oleh suatu fluida 
untuk mengalir, maka akan memiliki nilai viskositas yang lebih tinggi. Dari gambar 4.3 juga dapat dilihat bahwa semakin besar volume pelarut yang digunakan, maka nilai viskositas nya juga akan meningkat. Hal ini disebabkan karena viskositas berbanding lurus dengan konsentrasi larutan. Suatu larutan dengan konsentrasi tinggi akan memiliki viskositas yang tinggi pula, karena konsentrasi larutan menyatakan banyaknya partikel zat yang terlarut tiap satuan volume. Semakin banyak partikel yang terlarut, gesekan antar partikel semakin tinggi dan viskositasnya semakin tinggi pula. Berbeda dengan suhu jika suhu semakin tinggi maka viscositas akan semakin rendah. Penelitian ini memiliki nilai viskositas yang diperoleh antara 0,1296-1 cP. Hasil terbaik yang didapatkan adalah pada volume $700 \mathrm{~mL}$ dengan waktu esktraksi selama 5 jam menggunakan pelarut n-heksan dan suhu $60^{\circ} \mathrm{c}$, dimana viskositas minyak yang dihasilkan yaitu 1 cP.

\subsection{Perbandingan Volume Pelarut dan Suhu Ekstraksi Terhadap Kadar FFA $(\%)$}

Adapun grafik perbandingan volume pelarut dan suhu ekstraksi terhadap kadar FFA (\%) dalam minyak biji orok-orok dapat dilihat pada Gambar 4.4 dibawah ini.

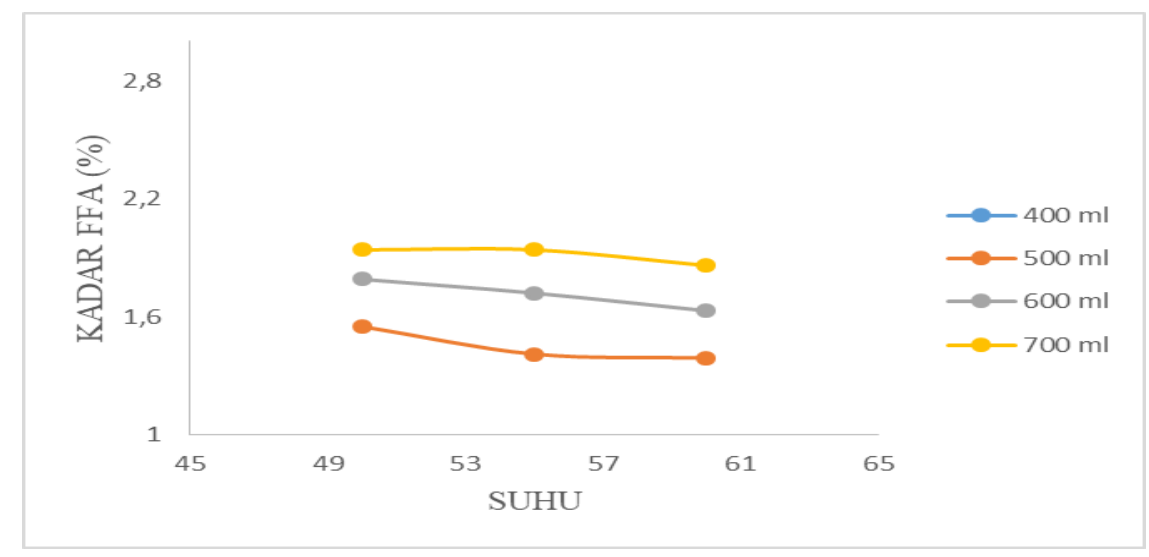

Gambar 4.4 Grafik Perbandingan Volume Pelarut dan Suhu Ekstraksi Terhadap Kadar FFA Minyak Biji Orok-Orok Menggunakan Pelarut n-Heksan.

Asam lemak bebas ditentukan sebagai kandungan asam lemak yang terdapat paling banyak dalam minyak tertentu. Free Fatty Acid (FFA) merupakan 
salah satu produk hasil hidrolisis dan oksidasi minyak dengan berat molekul rendah, bersifat mudah menguap dan bersama-bersama dengan yang lain menghasilkan bau tengik dan rasa yang tidak enak (Ketaren, 1986)

Bilangan asam pada minyak diinginkan max 0,8\%. Kadar asam lemak yang tinggi menyebabkan minyak mudah teroksidasi. Kadar asam lemak pada penelitian ini didapat paling rendah adalah $1 \%$. Kadar asam lemak yang tinggi di indikasi banyak mengandung air. Hal ini terjadi karena proses destilasi atau pemurnian yang tidak berjalan optimal.

Free Fatty Acid (FFA) merupakan salah satu produk hasil hidrolisis dan oksidasi minyak dengan berat molekul rendah, bersifat mudah menguap dan bersama-bersama dengan yang lain menghasilkan bau tengik dan rasa yang tidak enak (Ketaren, 1986). Adapun pengaruh waktu ekstraksi volume ekstraksi dan suhu ekstraksi dapat dilihat pada gambar 4.4. Gambar 4.4 dapat dilihat bahwa kadar FFA menurun seiring bertambahnya waktu ekstraksi dan dapat dilihat juga bahwa semakin besar volume pelarut yang digunakan, maka semakin kecil nilai kadar air yang dihasilkan. Hal ini disebabkan karena nilai kadar air dalam minyak biji orok-orok sangat menentukan tingkat kemurnian minyak yang dihasilkan. Semakin tinggi kadar air yang dihasilkan, maka semakin rendah kemurnian minyak yang diperoleh. Hal ini dikarenakan adanya sejumlah air dalam minyak yang dapat menyebabkan terjadinya proses hidrolisis sehingga mengakibatkan kerusakan minyak. Semakin tinggi kadar air suatu minyak, maka semakin besar pula kemungkinan terjadinya proses hidrolisis. Pada penelitian ini nilai kadar FFA yang diperoleh antara 1,39-2,62 \%. Hasil terbaik yang didapatkan adalah pada volume $500 \mathrm{~mL}$ dengan waktu esktraksi selama 5 jam dan suhu sebesar $50^{\circ} \mathrm{c}$ menggunakan pelarut n-heksan, dimana kadar FFA rendah hanya 1,39\%.

\subsection{GC-MS}

Kandungan kimia yang terdapat pada minyak biji orok-orok di uji dengan GC-MS. Suhu kolom $120^{\circ} \mathrm{C}$, suhu injeksi $250^{\circ} \mathrm{C}$ dan tekanan $100 \mathrm{Kpa}$. Gambar 4.5 menunjukkan kromatogram sampel minyak biji orok-orok dan tabel data 
waktu retensi serta luas puncak berdasarkan hasil GC-Ms. Sedangkan data waktu retensi dan luas puncak hasil dari analisis GC-MS dapat dilihat pada Tabel 4.2.

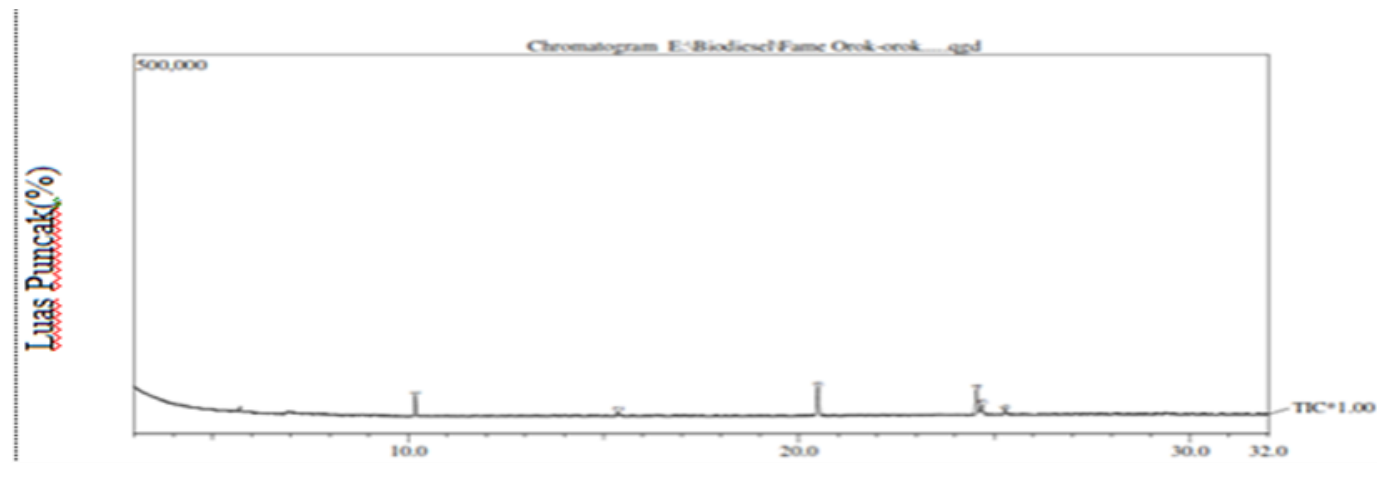

Waktu retensi (Menit)

\begin{tabular}{|l|l|l|}
\hline R.time & Area \% & \multicolumn{1}{c|}{ Senyawa Minyak Orok-orok } \\
\hline 10.187 & 18,85 & Methyl ester of undecanoic acid $\left(\mathrm{C}_{12} \mathrm{H}_{24} \mathrm{O}_{2}\right)$ \\
\hline 15,371 & 3,95 & 2-methylpentanoic acid $\left(\mathrm{C}_{6} \mathrm{H}_{12} \mathrm{O}_{2}\right)$ \\
\hline 20,488 & 30,85 & Myristic acid methyl ester $\left(\mathrm{C}_{15} \mathrm{H}_{3} \mathrm{O}_{2}\right)$ \\
\hline 24,551 & 27,29 & Methyl linolelaidate $\left(\mathrm{C}_{19} \mathrm{H}_{34} \mathrm{O}_{2}\right)$ \\
\hline 24,683 & 14,77 & 2-cyclopentylacetohydrazide $\left(\mathrm{C}_{7} \mathrm{H}_{14} \mathrm{~N}_{2} \mathrm{O}\right)$ \\
\hline 25,280 & 4,30 & 2-methylpentanoic acid $\left(\mathrm{C}_{6} \mathrm{H}_{12} \mathrm{O}_{2}\right)$ \\
\hline
\end{tabular}

Gambar 4.6 Kromatogram Minyak Kacang Tanah dengan Pelarut Etanol

Dari gambar 4.5 dapat dilihat bahwa analisa dengan menggunakan Gas Chromatoghraphy Mass Spectrometry (GC-MS) bertujuan untuk mengetahui senyawa yang terkandung didalam metil ester minyak dari minyak biji orok-orok. Analisa dengan menggunakan GC-MS menghasilkan puncak-puncak spektra yang menunjukkan jenis senyawa yang spesifik. Suatu senyawa dikatakan mirip dengan senyawa standar apabila memiliki berat molekul yang sama, pola fragmen yang mirip, dan harga SI (indeks kemiripan) yang tinggi. Berdasarkan pada gambar 4.5 kromatogram menunjukkan adanya 6 senyawa dalam minyak biji orok-orok.

\section{Simpulan dan Saran}


Dari hasil pengujian yang telah dilakukan, kesimpulan yang dapat diambil peniliti antara lain: hasil uji densitas terendah dihasilkan pada suhu $50^{\circ} \mathrm{C}$, Yield tertinggi dihasilkan pada suhu $60^{\circ} \mathrm{C}$, berat sampel $100 \mathrm{gr}$ dan waktu ekstraksi 5 jam, volume pelarut $700 \mathrm{~mL}$ sebesar $35.52 \%$, kadar FFA terendah dihasilkan pada suhu $50^{\circ} \mathrm{C}$, berat sampel 100 gr dan waktu ekstraksi 5 jam, volume pelarut

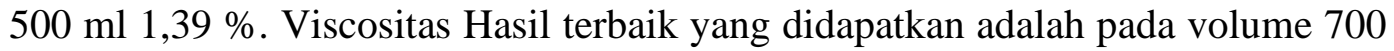
mL dengan waktu esktraksi selama 5 jam. menggunakan pelarut $n$-heksan dan suhu $60^{\circ} \mathrm{c}$, viskositas minyak yang dihasilkan yaitu $1 \mathrm{cP}$. untuk uji GC-MS terdapat komposisi minyak yang dihasilkan yaitu minyak biji orok-orok mengandung methyl ester of undecanoic acid, 2-methylpentanoic acid, myristic acid methyl ester, methyl linolelaidate, 2-cyclopentylacetohydrazide dan 2methylpentanoic acid. Berdasarkan penelitian yang telah dilakukan maka dapat diberikan saran untuk penelitian berikutnya adalah sebagai berikut: Proses pengadukan saat ekstraksi berlangsung sebaiknya lebih besar karena bahan baku bersifat padat agar pengadukan terjadi secara sempurna dan mengganti pelarut serta memvariasikan variable bebas yang mempengaruhi proses pembuatan minyak biji orok-orok agar menyelesaikan sampai tahap biodiesel.

\section{Daftar Pustaka}

1. Hadrah., Kasman, M., Sari, F.M., 2018. "Analisis Minyak Jelantah sebagai Bahan Bakar Biodiesel dengan Proses Transesterifikasi”. Universitas Batanghari: Jambi.

2. Jayanuddin, dkk, 2014. "Pengaruh Suhu Dan Rasio Pelarut Ekstraksi Terhadap Rendemen Dan Viskositas Natrium Alginat Dari Rumput Laut Cokelat (Sargassum sp)”. Fakultas Teknik, Jurusan Teknik Kimia, Universitas Sultan Ageng Tirtayasa.

3. Ketaren, S. 1986. Pengantar Teknologi Minyak dan Lemak Pangan. Cetakan Pertama. Jakarta : UI-Press. Mangoensoekarjo, S. 2003.

4. Martini Rahayu 2005. Teknologi Proses Produksi Biodiesel "www.Geocities.com/markal_bppt/public

4. Moeksin, Rosdiana.dkk “ Pengaruh Ukuran Partikel dan Jenis Pelarut Serta 
Waktu Ekstraksi Terhadap Yield Minyak Piper Retrofractum Vahl”. Fakultas Teknik, Jurusan Teknik Kimia, Universitas Sriwijaya, Indralaya.

5. Plantamor. 2008. "Plantamor Situs Dunia Tumbuhan, Informasi SpesiesPala"

6. Ramadhan, A.E. dan Phaza, H.A., 2010. Pengaruh Konsentrasi Etanol, Suhu dan Jumlah Stage pada Ekstraksi Oleoresin Jahe (Zingiber officinale Rosc.) Secara Batch, Skripsi, Universitas Diponegoro, Semarang.

7. Tiara, Muhammad, Masrulita. 2019. Pemanfaatan Biji Orok-Orok (Crotalaria juncea) sebagai BahanBaku Pembuatan Minyak Nabati dengan Metode Ekstraksi Padat-cair. Jurnal Teknik Kimia Universitas Malikussaleh 2019. 8:2 